\title{
THE RESULTS OF A COMPARATIVE STUDY OF THE EXAMINATION QUESTIONS FRAMED BY STATE BOARDS OF BAR EXAMINERS ${ }^{1}$
}

"How must a partnership exist?"

"What is the origin of the maxim, Consensus non concubitus facit matrimonium?"

"What are the great private economic relations of life and how do they arise?"

"Name the twelve maxims of Equity, using either Latin or English words (Latin preferred), and in giving these maxims, state them just as near as you can as stated by the text books on Equity."

These questions were not written by a jesting Rabelais for a juridical comic supplement, but were asked at an official Stateconducted examination for admission to the bar in June, IgI4. Many a bar examination paper truly affords glimpses of the possibilities of the grotesque not outdone by Robert Browning's "Caliban upon Setebos."

You ask: Can such things be? Have Langdell and Ames and Keener lived, and taught, and written in vain? Are not true shrines of legal education widely and bountifully maintained?

And the answer is: A shabby trick of memory such as the recollection of twelve equitable maxims, "Latin preferred," is a far more precious endowment to the candidate, for bar examination purposes in many states, than the ability to think clearly, analyze accurately and discriminate properly along approved legal lines. Of what conceivable value is sound training when tested by the memorization of wise saws, definitions, and Latin maxims?

What kind of nonsense, what order of foolishness is it, that impels us lawyers to agree that the vital necessity for the law student is his acquisition of the power of logical analysis and thoughtful discrimination in handling legal propositions, and at the same time, leads us to furnish many a bar examination paper calculated to test little more than his memory, and perhaps his sense of humor?

Impatience with the shortcomings of others, it has been said, is the measure of forgetfulness of our own. But there are times when impatience itself becomes a virtue.

\footnotetext{
${ }^{1}$ Paper read before the American Bar Association, Section of Legal Education, October Igth, Igr4.
} 
In the comparative study of recent question papers, a few of the points to be borne especially in mind are: (I) How much of the hypothetical as compared with the definitional question? (2) How much local variation in substantive common law? (3) How much statutory law? (4) How much local procedure? (5) How much jurisprudence, that is, "broad view of the law"? (6) How much business knowledge? Also, how much weight is laid upon the written test? Is it supposed to provide a comprehensive, adequate test of the applicant's fitness, or does it provide merely incidental evidence thereof? Of course, many other topics suggest themselves, but only the most vital can be considered herein.

In jumping at conclusions, you rarely land upon your feet. Despite the obvious truth of this, certain simple facts about to be set forth, sometimes in juxtaposition to other facts, lead to obvious and readily reached conclusions.

"Write your answers plainly on one side of the paper only and guard your spelling and punctuation."

This admonitory "note" appears at the beginning of each of the four subdivisions of a June, I9I4, bar examination paper. The thirty-first question contained two errors in spelling in one line. The thirty-ninth question read, "What is meant by the term corpus delicto (sic)." And these errors by no means stood alone.

Doubtless you have landed upon your feet in jumping at a conclusion with regard to this sort of carelessness. Doubtless, so did the young applicants.

The ninth question on the subject of Real Property on another June, I9I4, paper asked the candidate to "State the rule in Shelles' (sic) case." On another paper a question read: "What is easement and how are they (sic) acquired?" But enough of this!

On one recent examination paper, the twenty-third and thirtythird questions respectively read:

"What maxim of equity does Bispham say lies at the foundation of many of the important doctrines of equity?"

"Into what four classes has Lord Hardwicke divided fraud, as set out in Bispham?"

A candidate might be familiar with the classic works on Equity Jurisprudence by Story and Pomeroy, but Bispham alone-a far 
inferior work-provided the "Open Sesame" to his success. A candidate might be familiar with Ames' or Keener's excellent selections of cases on Equity and might be able to apply his learning so as to work out the correct answer to the most intricate and complicated problems in Specific Performance or Rescission, but of what avail was his training to him when he sought to answer these questions? Which was of more value to the candidate at that examination: a recollection of certain statements in Bispham's text, or possession of the capacity to reason convincingly and correctly along sound lines of legal scholarship? Is it jumping at a conclusion to assert that such questions as these afford, at best, only the weakest and most artificial variety of mental test? Does lack of knowledge of the elegantly worded generalities in Bispham stamp the candidate as unfit for practice?

Is not such a question as the following, asked at an examination held in 'Connecticut in May, I9I4, far preferable:

" $P$ holding a note of $X$ upon a secret trust for $M$, wrongfully indorsed and delivered it after maturity to $A$ who bought it in good faith. P subsequently collected the amount of the note of $\mathrm{X}$ the maker. Can A charge X upon the note? Reasons."

This question calls not only for a knowledge of equitable principles but for their logical. application. The latter is what the lawyer daily is called upon to do. The client does not ask his counsellor to state twelve equitable maxims, "Latin preferred," or to tell him what maxim Bispham says lies at the foundation of many equitable doctrines, but rather to apply correctly for him the appropriate principle to the facts. It follows, does it not, that more is needed than a mere lip-service to Bispham? And is it not also incontestable that the neophyte may possess the true touchstone to the highest legal success, though alas, unguided on his way by Bispham? And would you be jumping at a rash conclusion to say that such questions work a monstrous social, not to say, individual, injustice?

We are always profoundly critical of the examination papers of somebody else. At the same time, far too many bar examinations contain an overdose of definitional and informational questions. Bar examiners properly insist that the community has a right to expect a lawyer to know something about what the law actually is. One question at an examination held recently in a Middle Western state called for a knowledge of the general nature of preferred 
stock in a corporation. It was astounding and lamentable to see how many candidates knew absolutely nothing about preferred stock. Can such students really be said to know the subject of corporations? The point is it will not do to decry the informational side too much. It is not unreasonable for bar examiners to expect the possession of elementary knowledge. If any law school is emphasizing the acquisition of the legal mind at the expense of acquiring such information as any lawyer should possess, it is mistaking its function. "Training and knowledge, the means and the end of legal study, go hand in hand." On the other hand, the value of a lengthy string of questions calling for definitions and information and for little or nothing else, is gravely problematical. In one state, the ninth, tenth, eleventh and twelfth questions asked were:

"What are the essential elements of a negotiable instrument?" "What is the doctrine of extralateral rights?"

"What is (a) land, (b) tenements, (c) hereditaments?"

"What do you understand by the term 'Domestic Relations'?"

The first four questions on the same paper were:

"Define evidence."

"Define Equity, and state its origin in English law, and the causes of its existence."

"Define a contract."

"Define a private corporation, and distinguish it from a copartnership."

While questions with an informational object in view are not unwarranted, it is submitted that the form of such questions properly should call for the application of sound reasoning as well. The aim should be to emphasize logical thought moulded in grooves of legal scholarship, rather than mere poll-parroting by rule of thumb. That proper questions can be framed, the quiz papers not only of many law schools but of several bar examination boards clearly show.

For instance, let us suppose we wish to ascertain what the candidate knows about the topic of fixtures. How shall we frame the question? Shall we ask him, as one state board did last June,

"What are fixtures?"

Shall we ask him as another state board did last June, 
"What are the leading tests to be applied in determining whether or not personal property becomes a fixture?"

Or shall we ask him the following question framed last May in a third state:

"A lessee installs a motor and a machine in leased premises, the motor screwed to the wall and the machine set firmly in a concrete bed. After the lease expires and the tenant moves out of the premises he sends a truckman to remove the motor and the machine. The lessor refuses to allow the removal of the machine and motor. Has the lessee a remedy? Give reasons."

Which of these three questions shall we emulate? Shall we make it easy for ourselves and ask him to define fixtures, or to state the tests? Or shall we compel our candidate to exercise his gray matter as well as to ransack his memory, and give him a concrete state of facts, first to analyze, then to ponder over, and finally to solve, if he can, by the application of settled principles of the law of fixtures? True, it will be more difficult for us to frame the latter kind of question than for us to frame the former kind. But shall we be swayed by motives of ease rather than by motives of efficiency? Questions intelligently framed in proper form will make it well-nigh impossible for a candidate to attain success by the memorization of semi-understood rules in popular black-letter texts, or of semi-understood saws and maxims in legal primers fit alone for a kindergarten.

How much emphasis should be placed upon local decisions and statutes? If a candidate has a thorough grasp on the basic principles of the common law and exhibits sound habits of legal thought, should he suffer simply because his mind is not crammed with local technicalities whether legislative or judge-made? This is not to say that localized knowledge is not of value. It assuredly is. And it is fair and reasonable to require familiarity with such fundamental local law as the requisites of a valid will or the provisions of the state statute of frauds. Unfortunately, many examination boards have so over-emphasized acquaintance with mere local variations and anomalies as to convert an otherwise not unreasonable requirement into an unjust mockery. One state, for example, asks these two questions:

"What are the methods of creating a trust pointed" out by Chief Justice - in a leading case, and what is the name of the case?" 
"What was the purpose of I3 Eliz., c. 5, and of 27 Eliz., c. 4, and have those statutes been enacted into the Code?"

So, an applicant ought not to be required to "Give twenty statutory provisions relative to corporations," as another state demanded last June.

One possible aid in the solution of this problem is afforded by the examination paper of a New England board which allots thirty minutes of time to the answer of five questions on the local "constitution and statutes." In any event, the test primarily should be one of thorough absorption of fundamental principles, and should not degenerate into a petty search for provincial heterodoxies.

It is interesting to note an increasing desire to test general business and financial knowledge in so far as concerned with the law. Thus, a question like the following, asked in Maryland a year ago, seems to square well with modern corporate developments :

"What is the nature of what is called an agreement of underwriting of corporate securities; what is the purpose sought to be obtained; and how is the underwriter paid?"

Is it not essential for the candidate to have his attention directed to such timely and practical matters, so that when he is asked about the nature of underwriting he will not be in the position of the college boy who wondered whether the Renaissance was something good to eat?

As to how the examination paper should be subdivided and the weight to be placed upon individual subjects, no two states are in harmony. One state, for instance, will require no knowledge of international law. Another will devote two full questions to this topic, while alloting to constitutional law only three questions and to torts the same number.

The questions asked concerning constitutional law are often startling. One late paper asks the candidate to:

"Name four men who signed the Declaration of Independence," and to:

"Recite the Preamble to the Constitution of the United States."

Another sstate, famed for what it terms its progressivism, asked these two gems last June:

"What were the four great charters of English liberty?" 
"When was the Declaration of Independence made, and what was declared by it?"

In other jurisdictions we find these:

"Define treason under the statute of 36 George III, ch. 7."

"In Constitutional history which first had origin and development, State Government or Federal Government?"

"Give three general rules for the construction of constitutional provisions."

"When and where was the last Constitutional Convention held in this state?"

These questions serve to convict their framers of an utter failure to understand the splendid opportunity afforded by problems in constitutional law to test prowess in reasoning and in nice discrimination. Instead of asking for four signers of the Declaration, or to tell when the last Convention was held, or to imitate John Hancock's signature, it would seem a very simple matter, in this era of constant constitutional controversy, to frame questions like the following one, asked most opportunely in Rhode Island last March:

"The Federal Income Tax Law of I9I3 contains certain provisions in regard to "payment at the source" which require (I) every employer to withhold and deduct the tax from the salary of his employee and to make a return thereof and pay the tax to the Government; (2) every corporation to withhold and deduct the tax from interest upon its bonds and to make a return thereof and pay the tax to the Government; (3) every bank receiving coupons for collection to attach certificates to such coupons and to make a return to the Government. In the above cases additional expense is caused to the employer, the corporation and the bank by reason of the above requirements. What is your opinion in regard to the constitutionality of the above mentioned provisions of the Income Tax Law?"

It is said to-day that lawyers are unduly narrow. If that be so, all the more reason for requiring a broad, liberal training as a sine qua non to admission. Whether the candidate has this training can be ascertained upon a bar examination with comparative ease. Questions testing knowledge of jurisprudence and of legal history and development are well calculated to "read between the lines." Of course, they should not be over-indulged in. Consider the potent possibilities of these two questions recently asked in Pennsylvania : 
"Briefly discuss the origin, nature and use of the action of assumpsit at common law."

"When, and for what purpose was the statute of uses enacted; and what were the principal changes in the law of real property which resulted therefrom?"

In New Hampshire, last spring, the excellent first question on criminal law read:

"What was the common law theory of punishment and how far does it involve the ideas of (a) retribution, (b) protection of society, (c) reformation of the criminal?"

Though some bar examination boards call for the statement of twelve maxims of equity, "Latin preferred," it is equally true that some others frame admirable questions; some such have been quoted herein. And it is equally a fact, however sad, that the printed examination paper in equity of a state university law school shows that only last year it, too, requested its students to "Enumerate the twelve leading maxims of equity." However, the state university might be comforted perhaps by learning that last June a state board asked, "What are the thirteen maxims of equity?" No matter by whom asked, or when or where asked, such questions do not withstand the qualitative test, however they may respond to the quantitative.

The first hindrance in the way of improvement is found in the general attitude of indifference on the part of many members of the bar. They apparently share the sentiments of an Illinois lawyer, who in I9I2, when the Bar Association of that state was debating the subject of higher standards, said:

"It was remarked a good many hundred years ago that 'much learning hath made thee mad.' I do not sympathize with some of these modern things. My mind goes back to Abraham Lincoln when he was a poor boy, and if you go into Judge Landis' court room you will see pictured the table tipped over and the books on the floor and little Abe there reading the books. He was one of the greatest lawyers that ever walked the earth and he never saw the inside of a law school, in that sense; some of the best lawyers we ever had never were in a high school. *****

Now, in my case, I never saw the inside of a high school. A poor boy, at thirteen, I closed up my books and went as a drummer boy to the army and finally got to be large enough to carry a gun and I fought to keep the Union together. I read law in a telegraph office while I was a telegraph operator on the C. \& N. W. and elsewhere, and old Ed. Dutch in Oregon bought me 
the books and gave me Blackstone and he said, read it, but not like a novel; and I have sent whole chapters out of that Blackstone over the telegraph key while I was practicing; and I passed an examination of the Supreme Court and I passed 100 in the examination and I never saw a high school. **** Now give the boys a chance."

The theory of such lawyers seems to be: "Let them all leap over the bars; give all the boys a chance." This mistaken attitude on the part of many otherwise valuable members of the bar is directly responsible for much of the mischief. It is high time for the entire bar to realize that upon nothing do the competency and the dignity of the profession more directly depend than upon the standards of admission.

The second reason is found in the fact that most, if not indeed practically all, bar examiners are busy and well-known practitioners. The Supreme Courts seemingly wish such men as their law examiners and such men, of course, are not able to devote more than a limited amount of time to their duties. Besides, they have ordinarily not kept pace with improvements and developments in legal education, their attention being necessarily devoted to other matters. One member, at least, of every state board of bar examiners should be a comparatively young man who can devote his entire time, if needed, to his duties. $\mathrm{He}$ should be thoroughly acquainted with modern legal education. Preferably, but not necessarily, he should have had some lawteaching experience. Let him be styled the clerk or registrar of the board. Let him be paid a decent compensation. The resultant good to the profession, to the courts and to the community would be immeasurable. Under the prevailing system, the examiners mean well and do the best they can, in most cases, but they are greatly hampered because of the very merits and virtues for which they were selected.

Better bar examination questions mean raised standards of admission to the bar. Raised standards of admission to the bar mean better lawyers. Better lawyers mean a better brand of social and individual justice. Better justice means a nearer approach to a millennium of sweetness and of light.

I. MaURice Wormser.

New York City. 